\title{
Vegetation composition and soil microbial community structural changes along a wetland hydrological gradient
}

\author{
W. K. Balasooriya ${ }^{1}$, K. Denef ${ }^{2}$, J. Peters ${ }^{1}$, N. E. C. Verhoest $^{1}$, and P. Boeckx ${ }^{2}$ \\ ${ }^{1}$ Department of Forest and Water Management, Ghent University, Coupure links 653, 9000 Gent, Belgium \\ ${ }^{2}$ Department of Applied Analytical and Physical Chemistry, Ghent University, Coupure links 653, 9000 Gent, Belgium
}

Received: 4 October 2007 - Published in Hydrol. Earth Syst. Sci. Discuss.: 18 October 2007

Revised: 25 January 2008 - Accepted: 25 January 2008 - Published: 26 February 2008

\begin{abstract}
Fluctuations in wetland hydrology create an interplay between aerobic and anaerobic conditions, controlling vegetation composition and microbial community structure and activity in wetland soils. In this study, we investigated the vegetation composition and microbial community structural and functional changes along a wetland hydrological gradient. Two different vegetation communities were distinguished along the hydrological gradient; Caricetum gracilis at the wet depression and Arrhenatheretum elatioris at the drier upper site. Microbial community structural changes were studied by a combined in situ ${ }^{13} \mathrm{CO}_{2}$ pulse labeling and phospholipid fatty acid (PLFA) based stable isotope probing approach, which identifies the microbial groups actively involved in assimilation of newly photosynthesized, root-derived $\mathrm{C}$ in the rhizosphere soils. Gram negative bacterial communities were relatively more abundant in the surface soils of the drier upper site than in the surface soils of the wetter lower site, while the lower site and the deeper soil layers were relatively more inhabited by gram positive bacterial communities. Despite their large abundance, the metabolically active proportion of gram positive bacterial and actinomycetes communities was much smaller at both sites, compared to that of the gram negative bacterial and fungal communities. This suggests much slower assimilation of rootderived $\mathrm{C}$ by gram positive and actinomycetes communities than by gram negative bacteria and fungi at both sites. Ground water depth showed a significant effect on the relative abundance of several microbial communities. Relative abundance of gram negative bacteria significantly decreased with increasing ground water depth while the relative abundance of gram positive bacteria and actinomycetes at the surface layer increased with increasing ground water depth.
\end{abstract}

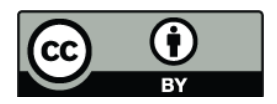

Correspondence to: W. K. Balasooriya (wajira.balasooriya@ugent.be)

\section{Introduction}

Wetland ecosystems are characterized by hydric soils which support hydrophilic vegetation (Mausbach and Parker, 2001). Fluctuations in wetland hydrology regulate the availability of oxygen, resulting in the interplay between aerobic and anaerobic processes of key biogeochemical cycles, such as nitrification, denitrification and methanogenesis (Davidsson et al., 1997). These wetland biogeochemical cycling processes are mostly microbially mediated. While wetland microbiology is receiving increasing research attention, it still remains under investigated. Wetland biogeochemistry research has mainly focused on (i) biogeochemical studies of processes, and, although less thoroughly studied, (ii) microbial ecological studies of populations and community structure (Gutknecht et al., 2006).

Hydrology is a dominant factor controlling microbial processes in wetlands (Bardgett and Shine, 1999; Gutknecht et al., 2006; Mentzer et al., 2006). Higher water levels increase the rate of anaerobic processes, such as denitrification (Smith and Tiedje, 1979), methanogenesis (Coles and Yavitt , 2004), and sulfate reduction (Devito and Hill , 1999), and decrease rates of aerobic processes, such as nitrification (Qiu and McComb, 1996) by creating low oxygen and anaerobic soil micro sites. In addition, temporal fluctuations of soil moisture from drying/wetting cycles stimulate denitrification in wet cycles and nitrification in dry cycles (Qiu and McComb, 1996; Venterink et al., 2002).

Additionally, hydrology affects vegetation composition since wetland plant species occurrence has been shown to be highly responsive to fluctuations in water level (Leyer, 2005; Van der Hoek and Sykora, 2006) and hydroperiod (Battaglia and Collins, 2006; Peters et al., 2007 $)$. Plants can influence

\footnotetext{
${ }^{1}$ Peters, J., Verhoest, N., Boeckx, P., Balasooriya, W. K., and Samson, R.: Hydrologic and vegetative analysis of an alluvial floodplain in Belgium, Belgian Journal of Botany, in review, 2007.
}

Published by Copernicus Publications on behalf of the European Geosciences Union. 
microbial functions directly by providing resources in litter (Bardgett and Shine, 1999), with variations among plant types or species depending on their nutrient content (Hume et al., 2002). Indirectly, plants affect microbial processes through their rhizosphere characteristics. The rhizosphere receives readily decomposable labile resources from plant roots (Kennedy, 2005) and increase oxygen levels relative to the surrounding wetland soil (Colmer, 2003).

While bacterial communities generally dominate the wetland soil microbial community (Boon et al., 1996), mycorrhizal fungi adapted to wetland conditions also occur (Anupam, 2003). Wetland hydrology may affect the general microbial community structure (Sundh et al., 1997; Mentzer et al., 2006), or specific organisms, such as mycorrhizal fungi (Wetzel and VanderValk, 1996). Wetland microbial community structure has also been shown to vary among plant species rhizospheres (Halbritter and Mogyorossy, 2002) and with plant community composition (Borga et al., 1994; Sundh et al., 1997; Ingham and Wilson, 1999).

Different biochemical and microbiological techniques have been used to describe the general structure of soil and aquatic microbial communities. In situ characterization of microbial community composition is commonly done through in situ analysis of specific components (biomarkers), which are only produced by and therefore characteristic for specific microbial groups. For example, the analysis of phospholipid fatty acids (PLFA) is based on the analysis of a group of cell membrane lipids, several of which can be used as biomarkers for specific microbial communities (Vestal and White, 1989; Zelles, 1997). The polar group of phospholipids is rapidly hydrolyzed upon microbial cell death, hence the fatty acids in intact phospholipids are assumed to originate from living micro organisms (White et al., 1979; Zelles, 1997). In wetland studies, PLFA analysis has shown microbial community compositional changes across different wetlands (Borga et al., 1994; Boon et al., 1996; Sundh et al., 1997) as a result of differences in hydrological fluctuations (Sundh et al., 1997; Mentzer et al., 2006). Although most PLFA studies have provided valuable information regarding the structure of the microbial community (Frostegard et al., 1993; Bossio et al., 1998; Steer and Harris, 2000; Fierer et al., 2003; Drissner et al., 2007), they usually do not reveal any information regarding the function of microbial communities associated with $\mathrm{C}$ cycling. Technological developments in mass-spectrometry in the last decades have made it possible to integrate stable isotope analysis into biomarker analysis (Boschker and Middleburg, 2002). The combination of ${ }^{13} \mathrm{C}$ stable isotope and PLFA analysis through Gas Chromatography-Combustion-Isotope Ratio Mass Spectrometry (GC-C-IRMS) has made it possible to trace the flow of $\mathrm{C}$ from a ${ }^{13} \mathrm{C}$-labeled substrate into the PLFA fraction of the microbial communities (Boschker et al., 1998), and to identify the microbial communities actively assimilating the labeled substrate-derived C. This combined approach is unique as it allows to assess the specifi- cally "active" proportion of the microbial community and to link biogeochemical processes with microbial identity. Stable isotope probing (SIP) of PLFA has been successfully attained through laboratory incubations with ${ }^{13} \mathrm{C}$ enriched substrate additions (Waldrop and Firestone, 2004), in situ enriched substrate additions (Williams et al., 2006), as well as in situ ${ }^{13} \mathrm{CO}_{2}$ pulse labeling of growing plants (Treonis et al., 2004; Prosser et al., 2006; Denef et al., 2007; Lu et al., 2007). By using in situ PLFA-based SIP analysis, several studies have demonstrated a dominant contribution of fungi in the immediate assimilation of rhizosphere-derived $\mathrm{C}$ in grasslands (Butler et al., 2003; Treonis et al., 2004; Olsson and Johnson, 2005; Denef et al., 2007). In this study, PLFAbased SIP was performed through an in situ stable isotope ${ }^{13} \mathrm{CO}_{2}$ pulse labeling approach in a natural wetland ecosystem to examine the incorporation of rhizodeposition into individual PLFAs across a spatial and temporal hydrological gradient. The main objective of this study was to examine if a wetland hydrological gradient and consequent vegetation composition distributions are linked to microbial community structural differences.

\section{Description of the study site}

The study was conducted along a topographical transect in the Northern part of the wetland nature reserve Bourgoyen-Ossemeersen, Ghent, Belgium. The BourgoyenOssemeersen is an alluvial complex characterized by floodplains of the river Leie. Higher levees are found next to the river with well drained sandy to silty textured soil types while floodplain depressions in the hinterland have clay soils with gleyic properties. The management of the BourgoyenOssemeersen aims at increasing the botanical and ornithological value of the nature reserve area. During winter (November-March), a floodgate is closed and the gravitational drainage of the area is blocked up to a height of $5.67 \mathrm{~m}$ a.s.1. The rate of ground water depth rising is dependent on the precipitation during this period. From the first of March on, gravitational drainage is allowed to a height of $5.27 \mathrm{~m}$ a.s.l., but evapotranspiration losses might further lower the actual ground water depth. The vegetation of Bourgoyen-Ossemeersen consists of several grassland associations. Areas with high productivity are mown twice a year (June and September), whereas areas with lower productivity are mown once a year. Some other parcels are seasonally grazed. Along the transect, an upper site on the levee and a lower site in the depression, each approximately $15 \mathrm{~m}$ long, were selected. Each of the two sites was subdivided in a left, middle and right sampling point (Fig. 1). The elevation ranges from $5.3 \mathrm{~m}$ a.s.l. at the lower site to $7 \mathrm{~m}$ a.s.l. at the upper site (Peters et al., 2006). Soil texture at the different sites could be summarized as: (i) clay soils at the lower site; (ii) a sandy loam soil texture at the upper left sampling point, and 
(iii) sandy soils at the upper middle and upper right sampling points.

\section{Methods}

\subsection{Monitoring of the eco-hydrological site conditions}

\subsubsection{Hydrological data}

At each sampling point (left, middle and right) of the lower and the upper site, soil water content reflectometers (CS616, Campbell Scientific Ltd.) were installed at 10 and $30 \mathrm{~cm}$ depths for measuring the volumetric water content (VWC) of the soil $\left[\mathrm{cm}^{3} \mathrm{~cm}^{-3}\right]$. In addition piezometers were installed and equipped with divers (TD Diver, Van Essen Instruments) to measure ground water depths relative to the soil surface. Details on the field position of the devices can be seen in Fig. 1. Hourly data recorded during a sampling period of two years (from 21 June 2005 until 21 June 2007) was extracted for this study. Additional information on precipitation was gathered from the nearby weather station Vinderhoute $(4 \mathrm{~km}$ from the study area), managed by the Flemish environmental agency VMM (hydronet databank http://www.hydronet.be). Time series of precipitation, ground water depth and soil water content are given in Figs. 2 and 3.

\subsubsection{Vegetation data}

Vegetation at the lower and the upper sites have been monitored on both floristic composition and vegetation structural variables. Floristic data were gathered by installing six permanent quadrats of $2 \mathrm{~m}$ by $2 \mathrm{~m}$ at both sites (12 quadrats in total), located near the three sampling points. In $\mathrm{Au}-$ gust 2006, the species composition within these quadrats was described, and the abundance of recorded species was estimated using the decimal Londo scale (Londo, 1976). The vegetation structure was described by means of two variables: living above ground biomass $\left[\mathrm{gm}^{-2}\right]$, and leaf area $\left[\mathrm{m}^{2} \mathrm{~m}^{-2}\right]$, which is the quotient of the total one-sided green leaf area and the ground area. Therefore monthly samples were taken by harvesting six randomly distributed $30 \mathrm{~cm}$ by $30 \mathrm{~cm}$ patches on the lower and upper site. Dead and living plant materials of the vegetation samples were separated prior to the determination of the leaf area using a LI-3100 leaf area meter (LI-COR Biosciences). Finally, the plant material was oven dried $\left(48 \mathrm{~h}, 70^{\circ} \mathrm{C}\right)$ and weighted to determine the above ground biomass.

3.2 Assessment of microbial community structure and function

\subsubsection{Experimental ${ }^{13} \mathrm{CO}_{2}$ pulse labeling}

In April and June 2007, ${ }^{13} \mathrm{CO}_{2}$ pulse labeling events were conducted. In April, pulse labeling was performed on three

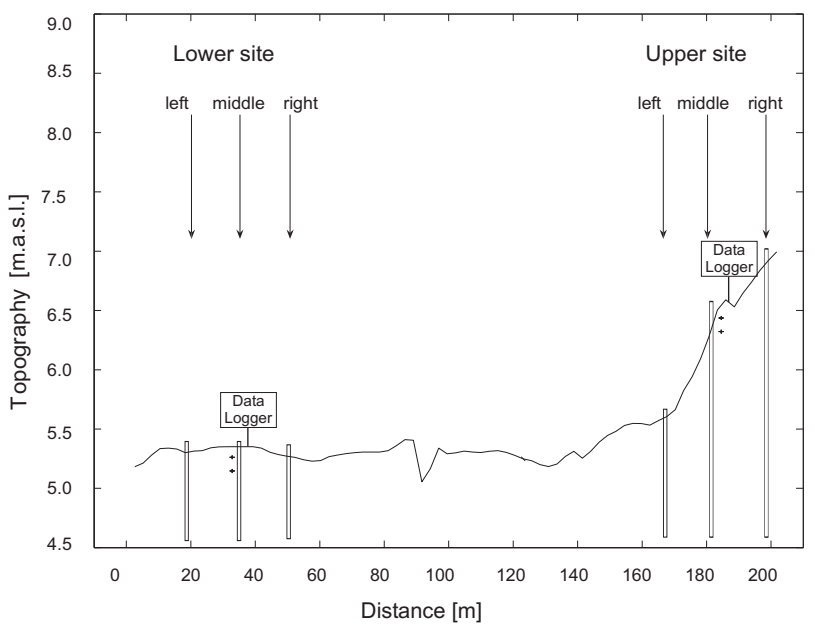

Fig. 1. Lower and the upper site along the topographical transect in the Bourgoyen-Ossemeersen. The left, middle and right sampling points at each site are indicated by arrows, long tubes are the piezometers and + indicates the soil water content reflectometers.

replicate plots at the lower site whereas in June, this was done on three replicate plots at both the lower and upper site on two consecutive days. For each pulse labeling event, $500 \mathrm{ml}$ of ${ }^{13} \mathrm{C}$ labeled (99 atom \%) $\mathrm{CO}_{2}$ was supplied to photosynthesizing plants inside a Plexiglass chamber $(30 \times 30 \times 30 \mathrm{~cm})$ over a period of 6 daylight hours. A Tedlar gas sampling bag (1L, Alltech) fixed to a $50 \mathrm{ml}$ gas sampling bulb with a stop cock was used in the field to temporarily store ${ }^{13} \mathrm{CO}_{2}$ gas from the pressurized gas bottle, and allowed sampling of a known volume of ${ }^{13} \mathrm{CO}_{2}$ gas at atmospheric pressure prior to injection into the labeling chamber. When the $\mathrm{CO}_{2}$ level in the chambers fell below $250 \mathrm{ppm}, 100 \mathrm{ml}$ of ${ }^{13} \mathrm{CO}_{2}$ was transferred into a $100 \mathrm{ml}$ gas tight syringe (1100, Hamilton) from the gas sampling bulb and injected into the labeling chamber through a septum. The injections were repeated four times more, approximately in one hour intervals. Each injection was done when $\mathrm{CO}_{2}$ levels inside the chambers were below $250 \mathrm{ppm}$. Three replicate chambers, placed $2 \mathrm{~m}$ apart were placed on top of stainless-steel frames firmly inserted in the soil to a depth of about $10 \mathrm{~cm}$. $\mathrm{CO}_{2}$ concentrations were monitored (EGM-4, PP systems) within the chambers during the 6 hour pulse labeling to follow the uptake of ${ }^{13} \mathrm{CO}_{2}$ by photosynthesizing plants. The next day, chambers were removed approximately 24 hours after the first labeled $\mathrm{CO}_{2}$ injection, when all respired ${ }^{13} \mathrm{CO}_{2}$ was completely taken up by plant photosynthesis.

\subsubsection{Sampling and $\delta^{13} \mathrm{C}$ determinations in solid samples}

From each pulse labeled square within a site $(n=3)$, soil samples at $0-10 \mathrm{~cm}$ and $10-20 \mathrm{~cm}$ depth and shoot samples were taken after $24 \mathrm{~h}$, immediately following the removal of 

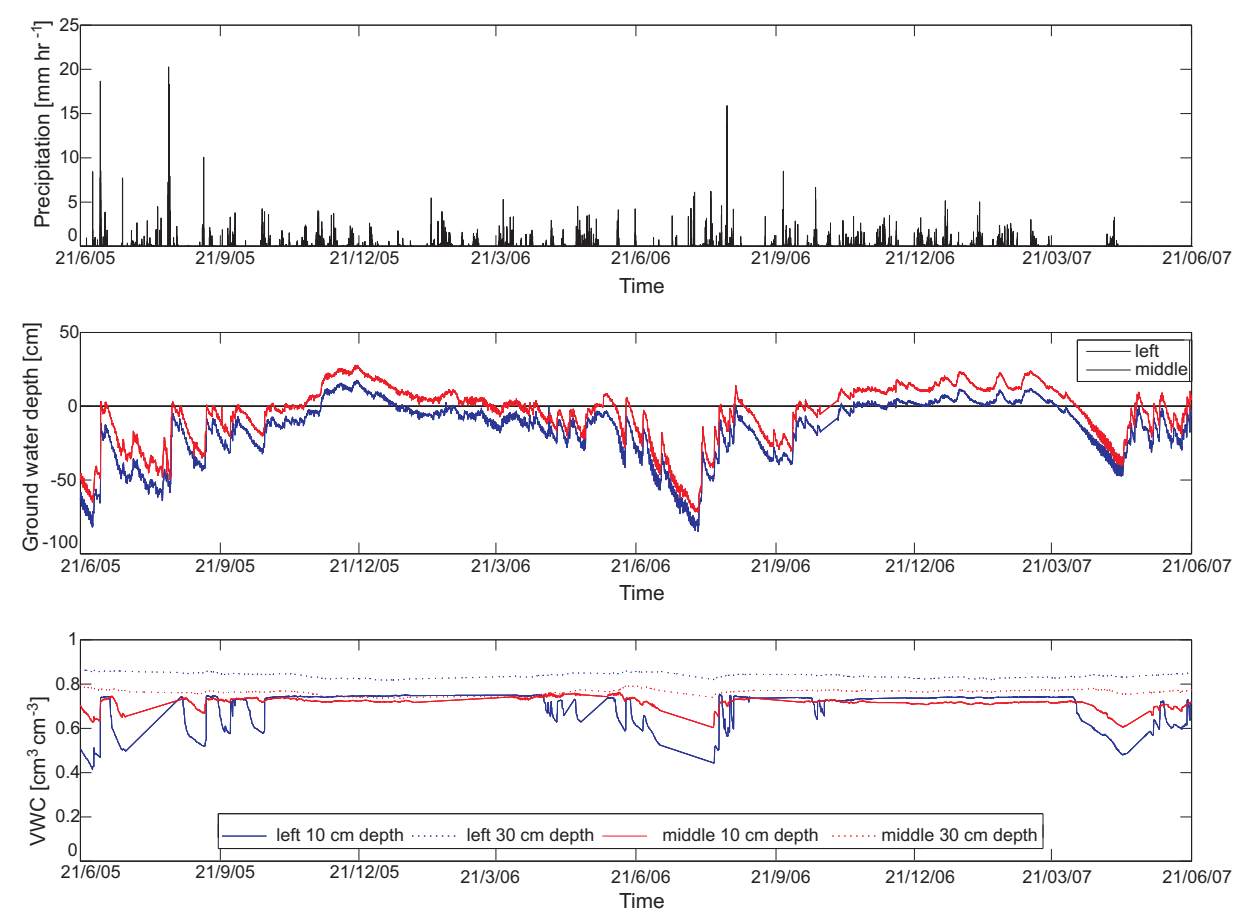

Fig. 2. Time series of precipitation, ground water depth and volumetric water content (VWC) in the lower site from 21 June 2005 to 21 June 2007.
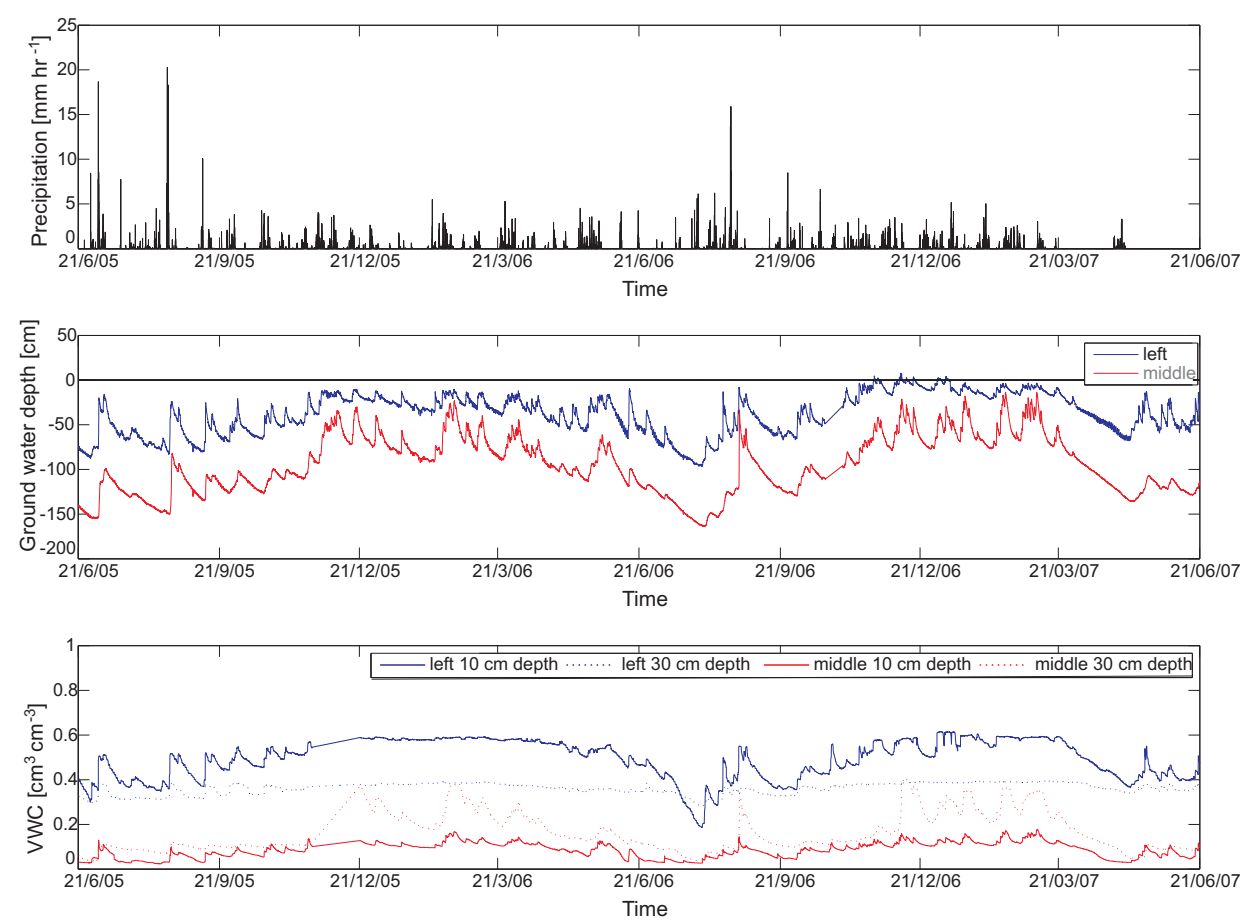

Fig. 3. Time series of precipitation, ground water depth and volumetric water content (VWC) in the upper site from 21 June 2005 to 21 June 2007. 
the chambers. In addition, composite samples of soil and shoots were taken prior to labeling as controls. All samples were immediately stored on ice and transported to the laboratory where soil samples were frozen $\left(-20^{\circ} \mathrm{C}\right)$. Later, soil samples were thawed and wet sieved through a $250 \mu \mathrm{m}$ sieve to remove all visible roots, macro fauna and fresh litter since plants contain large concentrations of the fungal

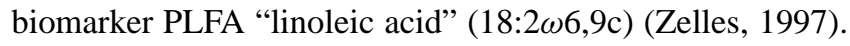
Direct dry sieving was not practicable due to high density of root mats and clayey texture in the samples from the lower site. The soil suspension from wet sieving was centrifuged at $2500 \mathrm{rpm}$ for $10 \mathrm{~min}$ and the pellet was immediately frozen $\left(-20^{\circ} \mathrm{C}\right)$ to recover the soil fraction. To obtain a dry sample for PLFA analysis, these frozen soil pellets were freeze dried. Dry sieving was done as the last step $(50 \mu \mathrm{m})$ in order to exclude any fine root hairs. Shoot samples and separated root fractions were oven dried $\left(24 \mathrm{~h}\right.$ at $\left.60^{\circ} \mathrm{C}\right)$ and then ground to a fine homogeneous powder using an ultra centrifugal mill (ZM200, Retsch Germany). A subsample of ground shoot and root samples $(1.5 \mathrm{mg})$ and soil samples $(20 \mathrm{mg})$ were analyzed for $\mathrm{C}, \mathrm{N}$ and ${ }^{13} \mathrm{C}$ content using an Elemental Analyzer (EA) (ANCA-SL, Europa PDZ, UK) coupled to an Isotope Ratio Mass Spectrometer (IRMS) (20-20, Sercon, UK) (EAIRMS). Samples measured in tin capsules were loaded into the EA using an auto sampler. The temperature at the combustion and reduction stages was $1800^{\circ} \mathrm{C}$ and $600^{\circ} \mathrm{C}$ respectively. Water is removed by a magnesiumperchlorate trap. Before entering the mass spectrometer, the gas stream passes a gas chromatograph which separates $\mathrm{CO}_{2}$ from $\mathrm{N}_{2}$ gas. In the IRMS $(90 \mathrm{eV}$ electron voltage, $144 \mu \mathrm{A}$ trap, He carrier gas, continuous flow, $10^{-7}$ mbar vacuum pressure, $90 \%$ focus) gaseous molecules are ionized in the ion source, then separated according to their mass-to charge ratio and finally collected in an array of Faraday cups (three Faraday cup collectors for $m / z 44,45$, and 46). Reference $\mathrm{CO}_{2}$ of known isotopic composition was used for sample calibration and introduced directly into the source three times at the start and end of each run. Each sample was run in duplicate to ensure reliable mean ${ }^{13} \mathrm{C}$ values. Isotope ratios were calculated as below (Dawson et al., 2002), and reported in terms of $\delta^{13} \mathrm{C} \%$ o (per mil) values.

$\delta^{13} \mathrm{C}=\frac{R_{\text {sample }}-R_{\text {reference }}}{R_{\text {reference }}} \times 10^{3}$

where $R_{\text {sample }}$ is the ${ }^{13} \mathrm{C} /{ }^{12} \mathrm{C}$ ratio of sample and $R_{\text {reference }}$ is the ${ }^{13} \mathrm{C} /{ }^{12} \mathrm{C}$ ratio of Vienna-Pee Dee Belemnite (V-PDB) reference standard from the IAEA. Finally the ${ }^{13} \mathrm{C}$ enrichment $\left(\Delta \delta^{13} \mathrm{C} \%\right.$ o) of shoot, root and soil samples was calculated by subtracting the pre-labeling natural abundance $\delta^{13} \mathrm{C}$ values from the post-labeling $\delta^{13} \mathrm{C}$ values of solid samples.

\subsubsection{PLFA extraction and quantification}

The extraction, quantification and compound specific $\delta^{13} \mathrm{C}$ analysis of PLFAs was performed following the method de- scribed by Denef et al. (2007). Total lipids were extracted from $6 \mathrm{~g}$ of soil using phosphate buffer/chloroform/methanol at a 0.9:1:2 ratio. Total lipids retrieved in the chloroform phase were partitioned on silica gel columns (CHROMABOND SiOH $500 \mathrm{mg}$ ). Neutral and glycolipids were eluted from these columns with $6 \mathrm{ml}$ of chloroform and $10 \mathrm{ml}$ of acetone and discarded. Phospholipids were eluted with $5 \mathrm{ml}$ methanol and the solution was dried under $\mathrm{N}_{2}$. Phospholipids were subsequently transesterified by mild methanolysis (1:1 methanol-toluene, $0.2 \mathrm{M}$ methanolic $\mathrm{KOH}$, heated for $15 \mathrm{~min}$ at $35^{\circ} \mathrm{C}$ ) to form volatilizable fatty acid methyl esters (FAMEs). FAMEs were analysed by capillary gas chromatography combustion-isotope ratio mass spectrometry (GC-C-IRMS) (GC-C/Delta ${ }^{\text {PLUS }} \mathrm{XP}$ Thermo Scientific) via a GC/C III interface. The gas chromatograph (splitless mode; He carrier gas) was equipped with a Chrompack CP-SIL88 column $(100 \mathrm{~m} \times 0.25 \mathrm{~mm}$ i.d. $\times 0.2 \mathrm{~mm}$, Varian Inc.). The oven temperature was programmed at $75^{\circ} \mathrm{C}$ for $2 \mathrm{~min}$, followed by a ramp at $5^{\circ} \mathrm{C} \mathrm{min}^{-1}$ to $180^{\circ} \mathrm{C}$ with a $20 \mathrm{~min}$ hold, and a final ramp at $2^{\circ} \mathrm{Cmin}^{-1}$ to $225^{\circ} \mathrm{C}$ with a $20 \mathrm{~min}$ hold. Individual fatty acids were identified based on relative retention times compared to two internal standards (12:0 and 19:0) which were added to the FAME extract prior to gas chromatography and cross referenced with several standards: a mixture of 37 FAMEs (37 component FAME mix, no. 47885, Supelco Inc.), a mixture of 24 bacterial FAMEs (BAME mix, no. 47080 , Supelco Inc.) and several individual FAMEs (Supelco Inc. and Larodan Inc.).

On average, 25 PLFA peaks were detected and quantified, but only 14 were investigated in this study depending on their use as biomarker fatty acids for different microbial communities (Zelles, 1997). Fatty acid nomenclature consists of the total number of $\mathrm{C}$ atoms, a colon, and the number of double bonds. Then an " $\omega$ " and a number showing the position of the double bond in the chain, sometimes followed by a "c" or "t" for "cis" or "trans" configuration respectively. The prefixes "i", "a" and "10Me" refer to methyl branching at the iso and anteiso positions and the carboxyl group from the 10th carbon respectively. Cyclopropane fatty acids have the prefix "cy" (Sundh et al., 1997). The 14 biomarker PLFAs analysed within this data set included: $18: 1 \omega 9 \mathrm{c}$ and $18: 2 \omega 6,9 \mathrm{c}$ (indicative of saprotrophic fungi), 16:1 $\omega 5 \mathrm{c}$ (indicative of arbuscular mycorrhizal fungi (AMF)), i14:0, i15:0, i16:0, i17:0 and a17:0 (indicative of gram positive bacteria), cy17:0, $16: 1 \omega 7 \mathrm{c}$ and $18: 1 \omega 7 \mathrm{c}$ (indicative of gram negative bacteria) and 10Me16:0 and 10Me18:0 (indicative of actinomycetes) (Denef et al., 2007). In most GC chromatograms, a17:0 and $16: 1 \omega 7 \mathrm{c}$ peaks overlapped, leading to an identification based on the relative abundance of other biomarker fatty acids in the sample. Chromatographic peak area ratios of each individual PLFA to that of 16:0, a universal PLFA occurring in the membranes of all organisms, were determined. Peak area ratios less than 0.02 were excluded from the data set (Drijber et al., 2000). Based on regressions between peak area and 
Table 1. Cross-correlations between ground water depth changes and precipitation for different time lags $[\mathrm{h}]$ after the rainfall event.

\begin{tabular}{lcccc}
\hline & \multicolumn{2}{c}{ LOWER } & \multicolumn{2}{c}{ UPPER } \\
& left & middle & left & middle \\
\hline GWD vs. Precipitation & & & & \\
time lag 0 h & 0.22 & 0.16 & 0.20 & 0.19 \\
time lag 1 h & $\underline{0.37}$ & 0.22 & 0.30 & 0.24 \\
time lag 2 h & 0.23 & $\underline{0.32}$ & $\underline{0.40}$ & $\underline{0.31}$ \\
time lag 3 h & 0.20 & 0.24 & 0.30 & 0.28 \\
time lag 10 & 0.02 & 0.03 & 0.02 & 0.15 \\
\hline GWD vs. VWC & & & & \\
time lag 0 h & $\underline{0.31}$ & $\underline{0.25}$ & $\underline{0.51}$ & $\underline{0.62}$ \\
time lag 1 h & 0.17 & 0.14 & 0.19 & 0.25 \\
time lag 2 h & 0.12 & 0.12 & 0.16 & 0.22 \\
time lag 3 h & 0.06 & 0.077 & 0.08 & 0.10 \\
time lag 10 $\mathrm{h}$ & 0.006 & 0.016 & 0.02 & -0.009 \\
\hline GWD vs. VWC & & & & \\
time lag 0 h & $\underline{0.056}$ & $\underline{0.055}$ & $\underline{0.36}$ & 0.26 \\
time lag 1 h & 0.046 & 0.030 & 0.18 & $\underline{0.34}$ \\
time lag 2 h & 0.018 & 0.018 & 0.14 & 0.32 \\
time lag 3 h & 0.031 & 0.023 & 0.08 & 0.31 \\
time lag 10 h & 0.014 & 0.099 & 0.02 & 0.17 \\
\hline
\end{tabular}

Maximal cross-correlation values are underlined.

PLFA concentration of a dilution series of the quantitative "37 component FAME mix", the $\mathrm{C}$ concentrations [nmol g ${ }^{-1}$ soil] of the individual biomarker PLFAs in the soil samples were quantified (Denef et al., 2007). Relative proportions of the individual PLFA-C ([PLFA-C $]_{i}$ ) to total PLFA-C of the sample $\left(\mathrm{MC}_{i}\right)$ were calculated and expressed as PLFA$\mathrm{C} \mathrm{mol} \%$ as an indicator of relative abundance of microbial communities.

$\mathrm{MC}_{i}=\frac{[\mathrm{PLFA}-\mathrm{C}]_{i}}{\sum[\mathrm{PLFA}-\mathrm{C}]_{i}} \times 100$

\subsubsection{Compound-specific ${ }^{13} \mathrm{C}$ analysis}

In order to calculate $\delta^{13} \mathrm{C}$ value in each PLFA, the $\delta^{13} \mathrm{C}$ values of FAMEs obtained from GC-C-IRMS were corrected for the addition of the methyl group during transesterification.

$\delta^{13} \mathrm{C}_{\mathrm{PLFA}}=\frac{\left[\mathrm{N}_{\mathrm{PLFA}}+1\right] \delta^{13} \mathrm{C}_{\mathrm{FAME}}-\delta^{13} \mathrm{C}_{\mathrm{MeOH}}}{\mathrm{N}_{\mathrm{PLFA}}}$

where NPLFA is the number of $\mathrm{C}$ atoms of the PLFA component, $\mathrm{C}_{\mathrm{FAME}}$ is the $\delta^{13} \mathrm{C}$ value of the FAME and $\mathrm{C}_{\mathrm{MeOH}}$ is the $\delta^{13} \mathrm{C}$ value of methanol determined by EA-IRMS $(-36.7 \%$, $n=5)$.

The ${ }^{13} \mathrm{C}$ enrichment or net labeling of PLFAs $\left(\Delta \delta^{13} \mathrm{C} \%\right.$ o) was calculated by subtracting the pre-labeling natural abundance PLFA $\delta^{13} \mathrm{C}$ values from the post-labeling PLFA $\delta^{13} \mathrm{C}$ values. The proportion of root-derived PLFA-C was calcu- lated for each individual PLFA through the following equation (Williams et al., 2006):

$\mathrm{FC}_{i}=\frac{\delta_{l i}-\delta_{u i}}{\delta_{r}-\delta_{u i}} \times \mathrm{MC}_{i}$

where $\mathrm{FC}_{i}$ is the relative fraction of $\mathrm{C}$ in each PLFA derived from the 13C-labeled roots, $\mathrm{MC}_{i}$ is the relative mol $\%$ of PLFA-C in each PLFA to the total PLFA-C in the sample. $\delta_{l i}$ represents the $\delta^{13} \mathrm{C}$ of the PLFA-C in the post-labeled sample, $\delta_{u i}$ represents the $\delta^{13} \mathrm{C}$ of the PLFA-C in the pre-labeled sample, and $\delta_{r}$ represents the $\delta^{13} \mathrm{C}$ of the post-labeled roots. The relative proportion of root-derived PLFA-C $\left(\mathrm{P}_{\mathrm{F} i}\right)$ was then calculated for each individual PLFA using the following equation (Williams et al., 2006):

$\mathrm{P}_{\mathrm{F} i}=\mathrm{MC}_{i} / \sum \mathrm{FC}_{i} \times 100$

\section{Results and discussion}

\subsection{Spatio-temporal changes of eco-hydrological variables}

\subsubsection{Ground water depth}

A clear gradient in ground water depths can be observed along the studied transect. Temporal averages range from $4.6 \mathrm{~cm}$ and $15.5 \mathrm{~cm}$ below surface at the lower middle and left monitoring points respectively, to $37.9 \mathrm{~cm}$ and $94.7 \mathrm{~cm}$ below surface at the left and middle monitoring points of the upper site. Ground water depths showed an annual pattern, with a deeper ground water table during summer and a more superficial ground water table during winter. Although this pattern was observed at all measurement points, inundation only occurs at the lower site with average flood durations of three to five months during winter and spring. Beside the annual ground water fluctuations, a daily fluctuation can be observed at the lower site during dry periods. These fluctuations can be a result of ground water consumption through transpiration activities of phreatophytic plant species, similar to what was reported in many other studies (White, 1932; Engel et al., 2005; Schilling, 2007). During daytime, when plants are actively photosynthesizing, water consumption causes a drop down of the ground water table which is (partially) replenished during night. At the upper site, this phenomena is absent (upper middle) or less pronounced in amplitude (upper left) (Peters et al., 2007 ${ }^{1}$ ).

The cross-correlation function was calculated to inspect the relationship between hourly precipitation $\left[\mathrm{mm} \mathrm{h}^{-1}\right]$ and the change in ground water depth $\left[\mathrm{cm} \mathrm{h}^{-1}\right]$ for different time lags [h] after the rainfall event (Table 1). Maximal crosscorrelation values were found one or two hours after rainfall, since higher infiltration rates at the upper site compensate for the higher distance to the ground water table. The highest cross-correlation value was calculated at the upper left monitoring point and results from the high permeability of the soil, 
the relative superficial ground water table and the lack of inundation. At the lower site, notwithstanding a shallow mean ground water depth, cross-correlation values were found to be lower, which may be attributed to the winter inundations. During inundations, cross-correlations are low (0.13) due to saturated conditions compared to cross-correlation value during summer (0.49). At the upper middle monitoring point, cross-correlation is lowest, indicating the less pronounced response of the ground water table to a rainfall event. Because of the greater depth of the ground water table, a relatively large proportion of the precipitation water never reaches the ground water table as it is stored in the soil volume above.

\subsubsection{Soil water content}

At the lower site the volumetric water contents of the soil layers increases with increasing depth (Fig. 2). At $30 \mathrm{~cm}$ depth, a year round soil saturation results in a constant volumetric water content of around $0.8 \mathrm{~cm}^{3} \mathrm{~cm}^{-3}$. At $10 \mathrm{~cm}$ depth, saturation is only interrupt during summer, but even then values are very high (in the range of $0.5-0.7 \mathrm{~cm}^{3} \mathrm{~cm}^{-3}$ ). These high values result from the high amount of organic $\mathrm{C}$ in the top soil (Table 2). The time series of volumetric water contents at the upper middle and left point differ considerably. At the upper middle sampling point, volumetric water content increases with depth, and fluctuations are noticed in both. The upper left site, however, is characterized by a higher water content at $10 \mathrm{~cm}$ depth, and saturated soil water conditions at $30 \mathrm{~cm}$ depth.

The relation between precipitation and volumetric water content at different depths was evaluated using the crosscorrelations function. At a depth of $10 \mathrm{~cm}$ high correlations were found immediately after the rainfall event. At the upper site, correlations are twice as high as at the lower site due to the lack of winter inundation. A response of soil water content at a depth of $30 \mathrm{~cm}$ to precipitation is only present at the upper site.

\subsubsection{Vegetation}

Based on species occurrence and abundance data, two different vegetation associations could be distinguished along the transect using TWINSPAN (Hill, 1979): Caricetum gracilis Almquist 1929 at the lower site and Arrhenatheretum elatioris Braun 1915 at the upper site. Caricetum gracilis Almquist 1929 (Schaminée et al., 1995) is a Carex acuta L. dominated vegetation type with Ranunculus flammula L. and Galium palustre L. Arrhenatheretum elatioris Braun 1915 (Schaminée et al., 1996) is a grassland association with Arrhenatheretum elatioris (L.)J. \& C. Presl., Festuca rubra L., Plantago lanceolata L. and Ranunculus repens L. Ellenberg moisture figures (Ellenberg et al., 1992) indicate a clear gradient from species occurring at intermediately moist habitats at the upper site toward species occurring on hydric soils in the depression (Fig. 4).

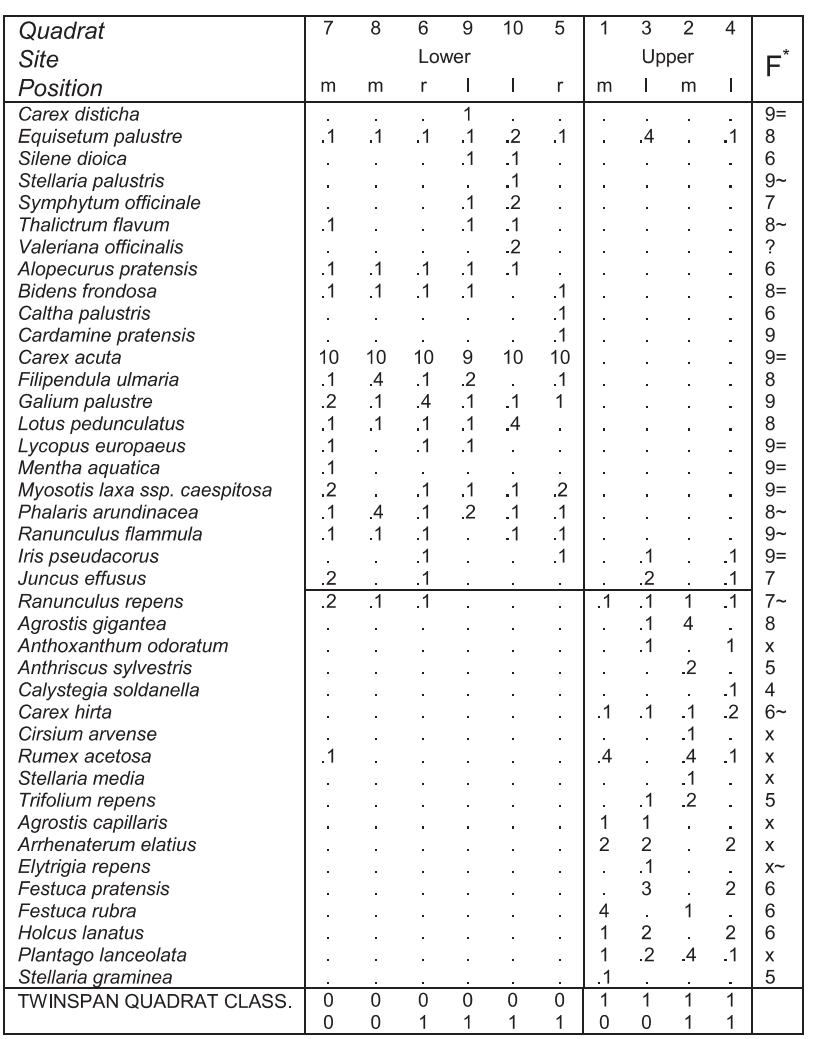

Fig. 4. Synoptic table of species abundances per quadrat $(.1<1 \%$, $.2=1-3 \%, .4=3-5 \%, 1=5-15 \%, 2=15-25 \%, 3=25-35 \%, 4=35-$ $45 \%, 5=45-55 \%, 6=55-65 \%, 7=65-75 \%, 8=75-85 \%, 9=85-95 \%$, $10=95-100 \%$ ), according to the Londo scale (Londo, 1976) and subdivided according to TWINSPAN (Hill, 1979). Quadrats are located near the left (l), middle (m) and right (r) sampling points of the upper and the lower sites (see Fig. 1). $\mathrm{F}^{*}$ Ellenberg moisture figure (Ellenberg et al., 1992), indicating the occurrence of plant species in the gradient from dry, shallow-soil rocky slopes to swampy ground (1-9) as well as from shallow to deep water (10-12). The symbol " " stands for changing moisture conditions, "=" for species of (temporarily) inundated habitats, " $\mathrm{x}$ " for indifferent species.

Vegetation structure was described during the year 2006 by means of above ground living biomass $\left[\mathrm{gm}^{-2}\right]$ and leaf area $\left[\mathrm{m}^{2} \mathrm{~m}^{-2}\right]$ (Table 3). Vegetation development started from zero at the lower site, and biomass and leaf area values did not increase very much during the period JanuaryApril. From May until July, a rapid increase in biomass (from $184.4 \mathrm{gm}^{-2}$ until $746.3 \mathrm{gm}^{-2}$ ) and leaf area (from $2.23 \mathrm{~m}^{2} \mathrm{~m}^{-2}$ until $8.27 \mathrm{~m}^{2} \mathrm{~m}^{-2}$ ) was measured, which was leveled off during August. In September, lower values were measured due to natural senescence. This was followed by a mowing event which drastically decreased above ground biomass $\left(-426.2 \mathrm{gm}^{-2}\right)$ and leaf area $\left(-3.26 \mathrm{~m}^{2} \mathrm{~m}^{-2}\right)$. A short regrowth period during November increased values slightly. The observed vegetation development differed quite a lot between the lower and the upper site. During winter, an 
Table 2. Isotope composition $\left(\delta^{13} \mathrm{C} \%\right.$ ) and $\delta^{13} \mathrm{C}$ enrichment $\left(\Delta \delta^{13} \mathrm{C} \%\right.$ ) of shoot, root and soil samples taken prior to (unl.) ( $n=3$ ), and $24 \mathrm{~h}$ after (lab.) $(n=3){ }^{13} \mathrm{CO}_{2}$ pulse labeling. Soil organic carbon content $(\%)$ is also included.

\begin{tabular}{|c|c|c|c|c|c|c|c|c|c|c|}
\hline \multirow[b]{2}{*}{ Month } & \multirow[b]{2}{*}{ Sample } & \multirow[b]{2}{*}{ Depth $[\mathrm{cm}]$} & \multicolumn{4}{|c|}{ LOWER } & \multicolumn{4}{|c|}{ UPPER } \\
\hline & & & Organic C & unl. $\delta^{13} \mathrm{C}$ & lab. $\delta^{13} \mathrm{C}$ & $\Delta \delta^{13} \mathrm{C}$ & Organic C & unl. $\delta^{13} \mathrm{C}$ & lab. $\delta^{13} \mathrm{C}$ & $\Delta \delta^{13} \mathrm{C}$ \\
\hline \multirow[t]{5}{*}{ April } & Shoot C & & & -28.02 & 2819.44 & 2847.46 & & & & \\
\hline & Root C & $0-10$ & & -28.38 & 4.42 & 32.80 & & & & \\
\hline & & $10-20$ & & -27.55 & -11.29 & 16.26 & & & & \\
\hline & Soil C & $0-10$ & 3.90 & -28.65 & -25.23 & 3.42 & & & & \\
\hline & & $10-20$ & 2.84 & -28.51 & -28.68 & -0.17 & & & & \\
\hline \multirow[t]{5}{*}{ June } & Shoot C & & & -27.90 & 1135.81 & 1163.71 & & -29.32 & 1289.40 & 1318.72 \\
\hline & Root C & $0-10$ & & -27.46 & -9.39 & 18.07 & & -29.29 & 26.76 & 56.05 \\
\hline & & $10-20$ & & -28.55 & -12.45 & 16.10 & & -24.66 & 61.83 & 86.49 \\
\hline & Soil C & $0-10$ & 8.82 & -28.42 & -25.90 & 1.81 & 2.52 & -28.29 & -22.12 & 6.17 \\
\hline & & $10-20$ & 4.06 & -29.06 & -27.46 & 1.60 & 1.43 & -27.85 & -25.6 & 2.24 \\
\hline
\end{tabular}

$\Delta \delta^{13} \mathrm{C}$ denotes the net increase of $\delta^{13} \mathrm{C} \%$ relative to natural abundance $\delta^{13} \mathrm{C} \%$ values of shoot, root and soil $\mathrm{C}$.

Table 3. Monthly data on biomass $\left[\mathrm{gm}^{-2}\right]$ and leaf area $\left[\mathrm{m}^{2} \mathrm{~m}^{-2}\right]$ at the lower and the upper site.

\begin{tabular}{lcccccccc}
\hline & \multicolumn{4}{c}{ LOWER } & \multicolumn{5}{c}{ UPPER } \\
Month & \multicolumn{2}{c}{ Biomass } & \multicolumn{2}{c}{ Leaf area } & \multicolumn{2}{c}{ Biomass } & \multicolumn{2}{c}{ Leaf area } \\
& \pm std & mean & \pm std & mean & \pm std & mean & \pm std \\
\hline Jan & 0 & - & 0 & - & 127.2 & 14.6 & 1.9 & 1.0 \\
Feb & 15.6 & 4.2 & 0.15 & 0.03 & 107.8 & 23.6 & 1.2 & 0.3 \\
Mar & 26.1 & 38.0 & 0.10 & 0.04 & 63.5 & 15.6 & 0.6 & 0.1 \\
Apr & 25.0 & 6.5 & 0.28 & 0.1 & 65.9 & 6.9 & 0.8 & 0.2 \\
May & 184.4 & 47.5 & 2.23 & 0.6 & 147.0 & 40.2 & 1.2 & 0.2 \\
Jun & 654.7 & 124.6 & 7.15 & 1.2 & 469.7 & 149.2 & 3.9 & 1.2 \\
Jul & 746.3 & 87.3 & 8.27 & 0.7 & 36.7 & 13.7 & 0.3 & 0.2 \\
Aug & 757.2 & 128.8 & 7.11 & 1.5 & 104.6 & 20.0 & 1.2 & 0.2 \\
Sep & 450.4 & 113.9 & 3.44 & 1.0 & 211.3 & 17.8 & 3.0 & 0.5 \\
Okt & 24.2 & 8.2 & 0.18 & 0.1 & 229.8 & 55.2 & 3.3 & 0.9 \\
Nov & 56.7 & 10.7 & 0.64 & 0.2 & 175.4 & 25.9 & 2.3 & 0.2 \\
Dec & 35.6 & 3.2 & 0.27 & 0.1 & 143.7 & 43.4 & 2.3 & 0.5 \\
\hline
\end{tabular}

above ground living biomass of $\approx 115 \mathrm{gm}^{-2}$ was measured, which decreased in March and April. As seen at the lower site, a fast increase in biomass and leaf area was measured during May and June, with maximal values of $469.7 \mathrm{gm}^{-2}$ and $3.9 \mathrm{~m}^{2} \mathrm{~m}^{-2}$, respectively. A mowing event at the end of June drastically decreased biomass $\left(-433 \mathrm{gm}^{-2}\right)$ and leaf area $\left(-2.7 \mathrm{~m}^{2} \mathrm{~m}^{-2}\right)$. Vegetation recovery was fast, and a second growing period after the mowing event resulted in biomass and leaf area values as high as $229.8 \mathrm{gm}^{-2}$ and $3.3 \mathrm{~m}^{2} \mathrm{~m}^{-2}$, respectively.

\section{2 microbial community structure and function}

\subsection{1 $\quad \delta^{13} \mathrm{C}$ enrichment of shoot, root and soil $\mathrm{C}$}

All 3 pulse labeling events in the lower and the upper sites resulted an increased $\delta^{13} \mathrm{C}$ signature of the shoot and root biomass (Table 2). Comparatively lower $\delta^{13} \mathrm{C}$ signatures (i.e. more negative or less positive) were observed in soil C, especially at the lower site, reflecting a small but significant incorporation of new plant photosynthate-C into the soil matrix. The larger background soil $\mathrm{C}$ at the lower the site (Table 2) possibly diluted the incoming $\delta^{13} \mathrm{C}$ from plants and may explain the observed lower ${ }^{13} \mathrm{C}$ enrichment of the soil $\mathrm{C}$ of the lower site compared to that of the upper site (Table 3). The data was presented as $\delta^{13} \mathrm{C}$ enrichment $\left(\Delta \delta^{13} \mathrm{C} \%\right.$ ) relative to pre-pulse labeling (control) samples to correct for initial $\delta^{13} \mathrm{C}$ differences between sites at each labeling event. Shoot biomass showed the highest $\delta^{13} \mathrm{C}$ enrichment, followed by root biomass and soil organic C. Enrichment of soil and root biomass was generally greater at the upper site compared to the lower site after the pulse labeling in June. Within the lower site, June labeling resulted in lesser $\delta^{13} \mathrm{C}$ 

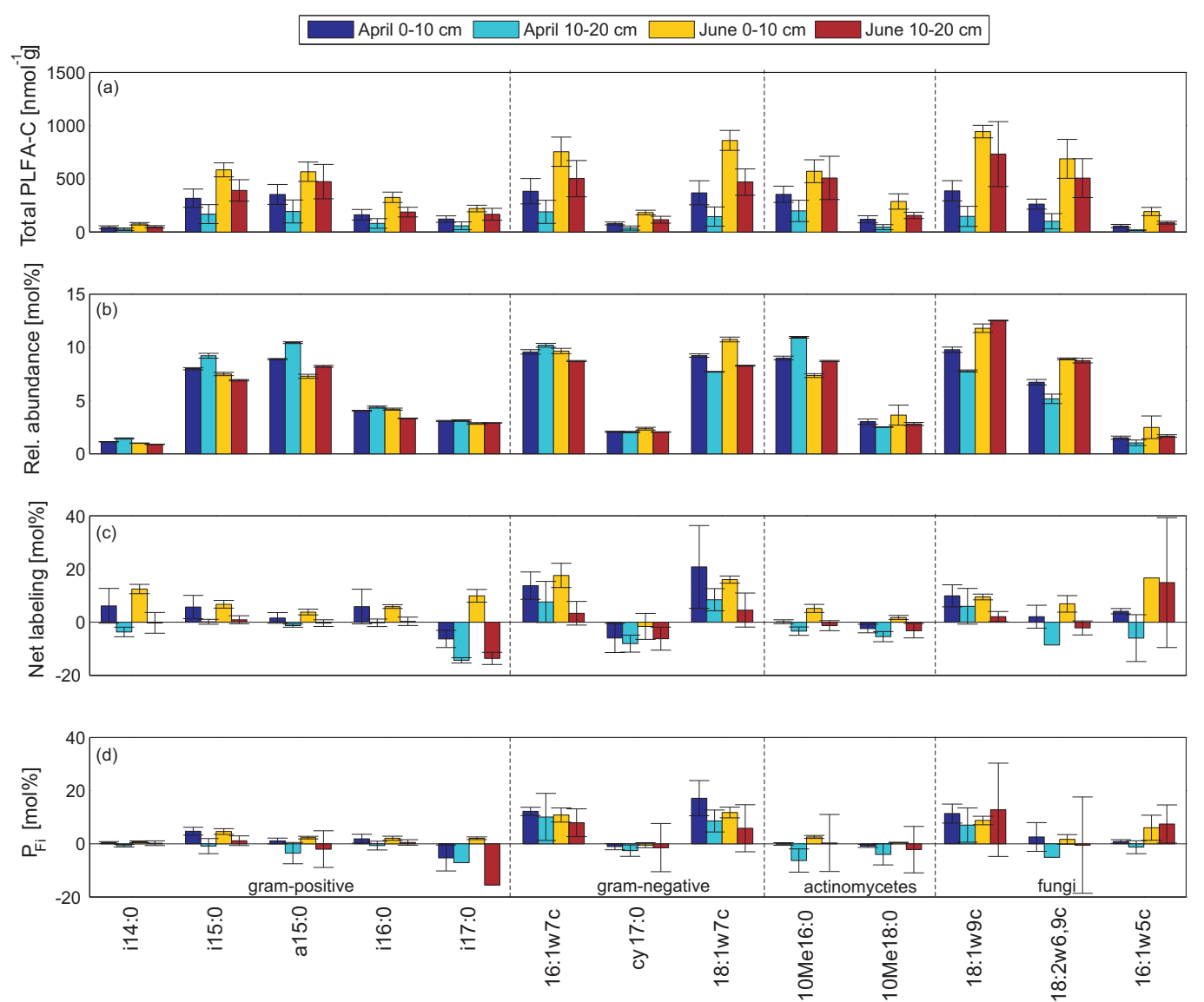

Fig. 5. The abundance of total PLFA-C in nmol g ${ }^{-1}$ soil (a), relative abundance of total PLFA-C $\left(\mathrm{MC}_{i}\right)$ in mol\% (b), net labeling or $\delta^{13} \mathrm{C}$ enrichment during labeling $\left(\Delta \delta^{13} \mathrm{C} \%\right.$ ) $(\mathbf{c})$, and relative abundance of root-derived PLFA-C $\left(\mathrm{P}_{\mathrm{F} i}\right)$ in mol\% (d) in different PLFA biomarkers found in the surface soils $(0-10 \mathrm{~cm})$ and subsurface soils $(10-20 \mathrm{~cm})$ at the lower site in April and June 2007.

enrichment of root biomass and soil $\mathrm{C}$ at $0-10 \mathrm{~cm}$ depth, than that in April. These differences were expected to be indicative of differences in microbial performance between sites and time periods, however, could have been shaded by differences in solar radiation and other climatic conditions prevailing during the different labeling events that control plant photosynthetic $\mathrm{CO}_{2}$ uptake and consequently the rhizodeposit$\mathrm{C}$ transport in the rhizosphere soil. Therefore, $\delta^{13} \mathrm{C}$-PLFA comparisons were performed after expressing the data as proportions of rhizosphere-derived PLFA-C of each individual fatty acid to that of the total rhizosphere-derived PLFA-C $\left(\mathrm{P}_{\mathrm{F} i}\right)$.

4.2.2 Spatio-temporal patterns of microbial community structure

Spatio-temporal patterns of PLFA profiles in the lower and upper sites are illustrated in Fig. 5 and Fig. 6. The comparisons between sites, time periods and soil depths were done by ANOVA. The concentration of individual PLFAs ([PLFA-
$\mathrm{C}], \mathrm{nmol} \mathrm{C}^{-1}$ soil), representing the abundance of the different microbial cell membrane biomarker lipids, was significantly higher $(p<0.05)$ in the lower site than in the upper site throughout the soil profile $(0-20 \dot{\mathrm{cm}})$ (Fig. 6a), indicating higher microbial abundance at the lower site. A general decline of [PLFA-C] occurred with depth at both sites showing decreasing microbial abundance with depth. A significantly greater [PLFA-C] of most of the individual PLFAs occurred in June compared to April at the lower site (Fig. 5a) at both depths indicating greater microbial abundance in June than April (except for i14:0, a15:0, 16:1 $\omega 7 \mathrm{c}$ and 10Me16:0 at 10$20 \mathrm{~cm}$ depth).

The relative abundance of individual PLFAs $\left(\mathrm{MC}_{i} \%\right)$ represent the relative proportions of the individual PLFA$\mathrm{C}\left([\mathrm{PLFA}-\mathrm{C}]_{i}\right.$ ) to total PLFA-C abundance (Fig. 5b and Fig. $6 \mathrm{~b}$ ). Gram positive bacteria associated fatty acids were relatively more abundant (higher $\mathrm{MC}_{i} \%$ ) in the wetter lower site and in the subsurface soils of the drier upper site than in the upper surface horizon. Among all gram positive PLFAs, this pattern was significant $(p<0.05)$ for i15:0, i16:0 and 

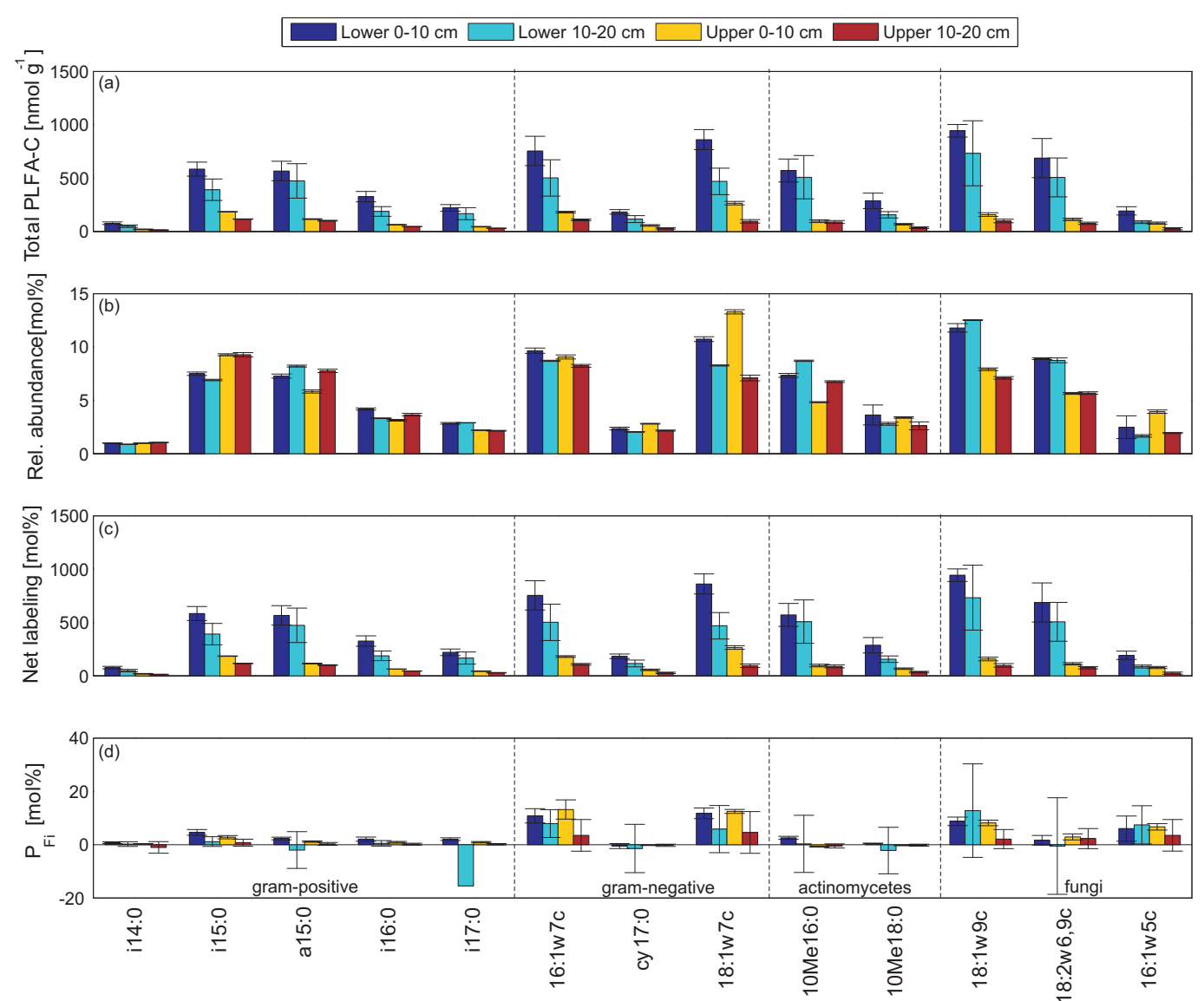

Fig. 6. The abundance of total PLFA-C in nmol g ${ }^{-1}$ soil (a), relative abundance of total PLFA-C $\left(\mathrm{MC}_{i}\right)$ in mol\% (b), net labeling or $\delta^{13} \mathrm{C}$ enrichment during labeling $\left(\Delta \delta^{13} \mathrm{C} \%\right.$ o $)(\mathbf{c})$, and relative abundance of root-derived PLFA-C $\left(\mathrm{P}_{\mathrm{F} i}\right)$ in mol\% (d) in different PLFA biomarkers found in the surface soils $(0-10 \mathrm{~cm})$ and subsurface soils $(10-20 \mathrm{~cm})$ at the lower site and the upper site in June 2007.

i17:0. A general decline of gram positive PLFAs was found with increasing soil depth, with a significant decline found in April for most of the gram positive PLFAs (i15:0, a15:0, i16:0, i14:0) $(p<0.05)$. The observed higher abundance of gram positive fatty acids in April (significant at $10-20 \mathrm{~cm}$ depth $p<0.05$ ) compared to that in June in the lower site further confirms the association of this set of fatty acids with anaerobic conditions which were prevalent in April than in June, as well as in deeper soil depths and in the lower site compared to the upper site.

The relative abundance of gram negative PLFAs was greater in the surface layer of the upper site than in that of the lower site (Fig. 5b and Fig. 6b). In the lower site, greater gram negative relative abundance occurred in the surface samples of June than in the surface samples of April. Among all gram negative bacterial PLFAs, $18: 1 \omega 7 \mathrm{c}$ was significantly more relatively abundant in the upper site than in the lower site $(p<0.01)$ and cy 17:0 and $18: 1 \omega 7 \mathrm{c}$ showed a significant decline in relative abundance with depth at both sites $(p<0.05)$.
Relative abundance of actinomycetes (10Me16:0) was significantly greater $(p<0.05)$ at the lower site than in the upper site and generally increased with depth (Fig. 5b and Fig. 6b). The relative abundance of arbuscular mycorrhizal fungal PLFA $(16: 1 \omega 5 c)$ was significantly greater $(p<0.05)$ in the upper site than in the lower site, while saprotrophic fungi associated PLFAs; $18: 1 \omega 9 \mathrm{c}$ and $18: 2 \omega 6,9 \mathrm{c}$ were significantly higher $(p<0.05)$ at the lower site. Fungal PLFAs were relatively high in the surface horizon compared to the subsurface layers. This decline with depth was significant for 18:1 $\omega 9 \mathrm{c}$ and 18:2 $\omega 6,9 \mathrm{c}$ fungal PLFAs in April at the lower site $(p<0.05)$ and for AMF $(16: 1 \omega 5 c)$ in June at the upper site $(p<0.05)$. However, the relative abundance of fungal PLFA 18:1 $\omega 9 \mathrm{c}$ was higher at the subsurface layer than at the surface layer in June at the lower site. Relative abundance of fungal PLFAs were generally higher in June compared to that in April at the lower site, while $18: 1 \omega 9 \mathrm{c}$ and $18: 2 \omega 6,9 \mathrm{c}$ fungal PLFAs in the surface layer were significantly relatively higher in June compared to that in April (Fig. 5b and Fig. 6b). 
Several other studies reported significant changes of soil microbial communities with depth or in response to landuse, management or environmental change based on PLFA analysis (Sundh et al., 1997; Fierer et al., 2003; Bossio et al., 2006). Similar patterns of relatively more abundant gram positive bacterial PLFAs in wetlands with prevailing anaerobic conditions as compared to more aerated agricultural fields, and decreased relative abundance of gram negative bacterial PLFAs with soil depth in both wetland and agricultural land uses were reported by Bossio et al. (2006). In addition, Bossio et al. (2006) suggested a higher growth rate of aerobic bacteria dominated communities compared to anaerobic bacteria dominated communities, based on PLFA indices. This study concluded that the aeration condition was the predominant determinant of abundances of the microbial communities across soil types and land usage. Sundh et al. (1997) found increasing gram positive bacteria and actinomycetes with depth (based on total PLFA concentrations), in dry sites of peatlands, and suggested that these shifts could be due to anaerobic conditions imposed by ground water depth. Other studies have detected relatively large actinomycetes populations in sub surface soils influenced by anaerobic conditions (Federle et al., 1986) and in podzol profiles under coniferous forest (Fritze et al., 2000). In our study, anaerobic conditions were expected in the lower site due to a year round shallow ground water depth compared to the upper site, where average ground water depth is below $30 \mathrm{~cm}$ (Figs. 2 and 3). Gram positive bacteria are known to have a strong association with anaerobic conditions (Sundh et al., 1997) prevailing in wetlands and with increasing soil depth, while gram negative bacteria are known to associate with well aerated conditions (Ponder and Tadros, 2002). Therefore, the observed shift from greater gram negative dominance at the well aerated soil surface in the upper site to greater gram positive dominance in the lower site and deeper depth, is consistent with the prevailing anaerobic conditions in the lower site and with increasing depth. Similar to our findings, Fierer et al. (2003) reported that gram positive bacteria as well as actinomycetes tended to increase in relative abundance with increasing soil depth, while that of gram negative bacteria and fungi were higher at the soil surface compared to that in the lower surface in two semi arid soil profiles. They concluded that the vertical distribution of these microbial groups can largely be attributed to the decline in carbon availability with soil depth. Griffiths et al. (1999) have shown that higher rates of $\mathrm{C}$ addition to soil will raise the proportions of fungi and gram negative bacteria in the microbial community and lower the proportions of actinomycetes and gram positive bacteria. In this study, greater biomass turnover occurred at the lower site than in the upper site (Table 3 ) indicating a higher $\mathrm{C}$ addition. Fungal PLFAs $(18: 1 \omega 9 \mathrm{c}$ and $18: 2 \omega 6,9 \mathrm{c})$ were higher at the lower site following the $\mathrm{C}$ availability. However, gram negative bacteria and AMF shifts were opposite than the predictions based on $\mathrm{C}$ availability, i.e. gram negative bacteria and AMF was higher at the surface layers of the upper site compared to that in the lower site. At the lower site, the aboveground plant biomass production was higher in June than in April, resulting in a temporal shift in the relative abundance of fungal PLFAs, i.e. greater relative abundance of fungal PLFAs in June than in April reflecting the greater $\mathrm{C}$ availability in June.

The advantage of the pulse labeling approach in combination with ${ }^{13} \mathrm{C}$ PLFA analysis is the identification of those microbial communities that are actively assimilating newly produced rhizosphere-C. The two ${ }^{13} \mathrm{C}$-PLFA based indices used in this study, i.e. net labeling $\left(\Delta \delta^{13} \mathrm{C} \%\right.$ ) and $\mathrm{P}_{\mathrm{F} i}$, distinguish the PLFAs associated with the metabolically-active proportion of the microbial communities from the PLFAs associated with the inactive or slow active proportion of the microbial communities with regard to rhizosphere $\mathrm{C}$ cycling (Denef et al., 2007). Net labeling was significantly higher in the surface layers of the upper site than that in the lower site $(p<0.05)$ in most of the individual PLFAs except for i14:0 and cy 17:0 (Fig. 5c and Fig. 6c). A general decline of net labeling occurred with depth. In June, net labeling was generally higher than in April at the surface layers of the lower

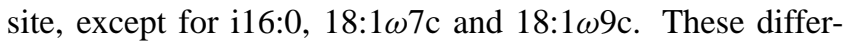
ences could be due to differences in microbial functioning between sites, depths and time periods, however, could be shadowed by differences in photosynthetic efficiency resulting in differences in ${ }^{13} \mathrm{C}$ input to the soil.

The relative abundance of root derived PLFA-C $\left(\mathrm{P}_{\mathrm{F} i}\right)$, which corrects for any differences in photosynthetic efficiency and was used as a measure for the active root-C assimilating portion of the microbial community structure, was generally greater at the surface layers compared to that in the subsurface at both sites except for 10Me16:0, 10Me18:0, and 18:1 $\omega 9 \mathrm{c}$ (Fig. 5d and Fig. 6d). In general $\mathrm{P}_{\mathrm{F} i}$ was higher in gram negative and fungal PLFAs at both sites than other groups confirming their relatively greater and rapid involvement in rhizosphere $\mathrm{C}$ cycling than the less active and slower growing gram positive bacteria and actinomycete communities at both sites. Rather than a uniform pattern of $\mathrm{P}_{\mathrm{F} i}$ of all PLFAs in both sites and periods, $\mathrm{P}_{\mathrm{F} i}$ of different microbial groups shifted differently between sites and time periods. For example, $\mathrm{P}_{\mathrm{F} i}$ of gram negative bacteria was generally greater in the surface layer of the upper site than that in the lower site while $\mathrm{P}_{\mathrm{F} i}$ of of gram positive bacteria was higher in the surface horizon of the lower site compared to that in the upper site. Gram negative $\mathrm{P}_{\mathrm{F} i}$ was generally higher in April than in June (except cy17:0) at the lower site, while gram positive $\mathrm{P}_{\mathrm{F} i}$ in the upper surface showed no prominent difference between April and June. Both gram negative and gram positive $\mathrm{P}_{\mathrm{F} i}$ generally decreased with depth. Among them, i14:0, i15:0 and i16:0 showed a significant decrease with depth at the lower site $(p<0.05)$, while i15:0, i16:0 and i17:0 significantly decreased with depth at the upper site $(p<0.05)$. Significantly higher $\mathrm{P}_{\mathrm{F} i}(p<0.01)$ was observed with actinomycetes at the lower site surface horizon compared to that in 
the upper site. At the lower site, actinomycetes (10Me 16:0) $\mathrm{P}_{\mathrm{F} i}$ significantly increased with depth $(p<0.05)$ and significantly greater $\mathrm{P}_{\mathrm{F} i}$ was found for 10Me16:0 and 10Me18:0 $(p<0.05)$ in June than in April. $\mathrm{P}_{\mathrm{F} i}$ of fungal PLFAs was not prominently different between two sites in the surface layer, while $\mathrm{P}_{\mathrm{F} i}$ of $18: 2 \omega 6,9 \mathrm{c}$ and $18: 1 \omega 9 \mathrm{c}$ in the subsurface layer of the lower site was greater than that in the subsurface layer of the upper site. AMF showed higher $\mathrm{P}_{\mathrm{F} i}$ in June than in April at the lower site, while the other two fungal PLFAs showed the opposite pattern between April and June. $\mathrm{P}_{\mathrm{F} i}$ of $18: 1 \omega 9 \mathrm{c}$ showed a significant decline with depth $(p<0.05)$ in lower April and upper June respectively. An increase of $\mathrm{P}_{\mathrm{F} i}$ with depth was observed for 18:1 $\omega 9 \mathrm{c}$ and AMF fungal PLFAs at lower June.

None of the previous studies on ${ }^{13} \mathrm{CO}_{2}$ pulse labeling based PLFA analysis, used $\mathrm{P}_{\mathrm{F} i}$ as an indicator to assess the proportion of those microbial communities that are actively assimilating root derived $\mathrm{C}$ in the rhizosphere. However, $\mathrm{P}_{\mathrm{F} i}$ has been successfully used by Williams et al. (2006) as an indicator to assess the active microbial communities assimilating 13C-labeled residue-derived $\mathrm{C}$ in rhizosphere by $\delta^{13} \mathrm{C}$ enriched straw addition under field conditions. Also a limited number of previous studies used ${ }^{13} \mathrm{CO}_{2}$ pulse labeling based PLFA analysis to assess the active microbial communities in root-derived $\mathrm{C}$ cycling in the rhizosphere (Butler et al., 2003; Treonis et al., 2004; Denef et al., 2007; Lu et al., 2007). Butler et al. (2003) pulse labeled rye grass in laboratory microcosms and found maximum labeling in the fungal PLFA $18: 2 \omega 6,9 \mathrm{c}$ in rhizosphere soils. Treonis et al. (2004) found greater net labeling of gram negative and fungal PLFAs than gram positive PLFAs at surface soil layer $(10 \mathrm{~cm})$ in upland grassland fields. Denef et al. (2007) assessed microbial community dynamics based on the proportional net labeling of individual PLFAs compared to that of a universal PLFA (i.e. 16:0) and found a rapid transfer of newly produced rhizosphere $\mathrm{C}$ to fungal PLFAs compared to bacterial PLFAs in the surface layers $(7.5 \mathrm{~cm})$ of grassland soils. Based on calculated net labeling in an in situ pulse labeling study of rice plants, Lu et al. (2007) reported that gram negative and fungi were most actively assimilating root-derived $\mathrm{C}$ in the rhizosphere, whereas gram positive microorganisms became relatively more important in the soil layer below the root zone. Our $\mathrm{P}_{\mathrm{F} i}$ results indicating a relatively greater active proportion of gram negative and fungal PLFAs in the rhizosphere at both sites are in consistent with the results of Butler et al. (2003); Denef et al. (2007); Lu et al. (2007). In agreement with $\mathrm{Lu}$ et al. (2007), we found greater active proportion of gram negative bacteria in the surface layer at the upper site compared to that in the subsurface layer. However, gram positive activity was depleted with depth in contrast to Lu et al. (2007).

The $\mathrm{P}_{\mathrm{F} i}$ of gram positive bacteria and actinomycetes at both sites was very low despite the observed higher relative abundances, indicating that more metabolically-inactive gram positive bacteria and actinomycetes were abundant in the rhizosphere soils at these sites or that these microbial communities were more dependent on other $\mathrm{C}$ resources such as soil organic $\mathrm{C}$ than newly produced-root derived $\mathrm{C}$. $\mathrm{P}_{\mathrm{F} i}$ of gram negative bacteria and fungal PLFA 18:1 $\omega 9 \mathrm{c}$ and AMF at both sites and fungal PLFA 18:2 $\omega 6,9 \mathrm{c}$ at the upper site were not substantially declined in relation to their relative abundances, suggesting that these microbial groups are more dependent on rhizodeposit- $\mathrm{C}$ as a $\mathrm{C}$ source for their growth. $\mathrm{P}_{\mathrm{F} i}$ of $18: 2 \omega 6,9 \mathrm{c}$ was rather low at the lower site despite its high relative abundance indicating, a preference of nonarbuscular mycorrhizal fungi for other $\mathrm{C}$ sources than new rhizodeposit-C at the lower site.

\subsection{Linking microbial community structure to hydrological changes and vegetation composition}

The observed shift from greater gram negative dominance at the well aerated soil surface in the drier upper site to greater gram positive dominance in the wetter lower site, is consistent with the patterns observed in other soil profiles (Sundh et al., 1997; Fierer et al., 2003; Bossio et al., 2006). However the underlying causes of these shifts were interpreted differently. Fierer et al. (2003) concluded that availability of C resources and not anaerobiosis was the underlying cause of these patterns while Bossio et al. (2006) concluded that aeration conditions, and not $\mathrm{C}$ availability per se were responsible for changes of microbial community structure. Hydrological changes are the key factors influencing aeration conditions of wetland soils (Davidsson et al., 1997). Anaerobic conditions can be expected in the lower site, due to inundation during winter months and a shallow ground water depth (GWD) throughout the year. In addition, the clayey soil texture in the lower site enhanced the water logged anaerobic condition of these soils. In the surface layer of the upper site, more aerobic conditions can prevail, due to the sandy loam texture of the soil and deep GWD, which never rises $30 \mathrm{~cm}$ underneath the soil surface. Monthly average GWD (over 2 years) in lower left and lower middle sampling points was $8.8 \mathrm{~cm}$ in April and that in June was $21.6 \mathrm{~cm}$. In upper left and upper middle sampling points the monthly average GWD in June was $83.3 \mathrm{~cm}$ and was significantly higher $(p<0.01)$ than corresponding June GWD value in the lower site. The relationship between ground water depth vs. the relative abundance (MC\%) of several microbial groups; gram positive, gram negative, actinomycetes and fungi (saprotrophic and AMF) was determined by linear regression. The relative abundance of a microbial group was calculated by summation of the relative abundances of individual PLFAs within the microbial group. Several groups showed significant relationships with GWD. The relative abundance of the gram negative bacteria at the surface layer significantly decreased with increasing GWD $\left(p<0.05, R^{2}=0.46\right)$, while the relative abundance of the gram positive bacteria in the surface layer was positively affected by increasing GWD $\left(p<0.05, R^{2}=0.40\right)$. The Ratio of the relative abundance of the gram negative bacteria over 
that of the gram positive bacteria $(\mathrm{Gn} / \mathrm{Gp})$ in the surface soils showed a significant negative relationship with the increasing GWD $\left(p<0.05, R^{2}=0.73\right)$. Actinomycetes were greatly increased with increasing GWD at the surface $(p<0.01$, $\left.R^{2}=0.95\right)$ and at the subsurface $\left(p<0.01, R^{2}=0.60\right)$ (Fig. 7$)$. These results suggest that anaerobic conditions imposed by incresaing GWD favor the abundance of gram positive bacteria and actinomycetes while gram negative bacteria prefer the aerobic surface layers where ground water is deep.

Soils in the lower site consisted of significantly greater ( $p<0.01)$ organic $\mathrm{C}$ content compared to the upper site (Table 2). Within the lower site, organic $C$ increased from April to June at the surface layers, while this increment was not significant at the subsurface. Linear regression functions were obtained between the organic $\mathrm{C}$ content vs. the relative abundance of several dominant microbial groups. None of the bacterial communities showed significant relationships with soil organic C. However, the relative abundance of fungi at the subsurface soils significantly increased with increasing soil organic $\mathrm{C}\left(p<0.05, R^{2}=0.74\right)$, indicating their dependence on soil organic $C$ resources at depth. Greater biomass growth rate of Caricetum gracilis at the lower site than Arrhenatheretum elatioris at the upper site could have caused greater soil organic $\mathrm{C}$ available in the lower site, explaining the unexpected larger abundance of saprotrophic fungal communities, which are aerobic (Mentzer et al., 2006) at the more anaerobic lower sites. Caricetum gracilis in the lower site was also associated with slow growing anaerobic bacterial communities, whereas Arrhenatheretum elatioris at the upper site was associated with fast growing aerobic bacterial communities in the surface soils. However, rather than the $\mathrm{C}$ availability, low $\mathrm{C}$ substrate quality, i.e. "low decomposability" in vegetated wetlands found to control the microbial community structure; (i.e. decrease the relative abundance of aerobic fast growing bacterial communities) (Bossio et al., 2006). We therefore expected a greater decomposability of Arrhenatheretum elatioris litter than Caricetum gracilis. Lower $\mathrm{C} / \mathrm{N}$ ratios (16.2) found for the shoot samples of $\mathrm{Ar}$ rhenatheretum elatioris than for the shoot samples of Caricetum gracilis (21.7) support this hypothesis. However, more research is needed on decomposition rates in line with SIPPLFA analysis to determine the effects of vegetation composition on soil microbial community structure.

\section{Conclusions}

The objective of the study was to investigate the effects of hydrology and vegetation composition on soil microbial community structural differences. The study site is characterized by a hydrological gradient, with superficial ground water levels at the depression and deeper ground water depth at the upper site. This hydrological gradient resulted in two different vegetation communities along the hydrological gradient; Caricetum gracilis at the depression and Arrhenatheretum

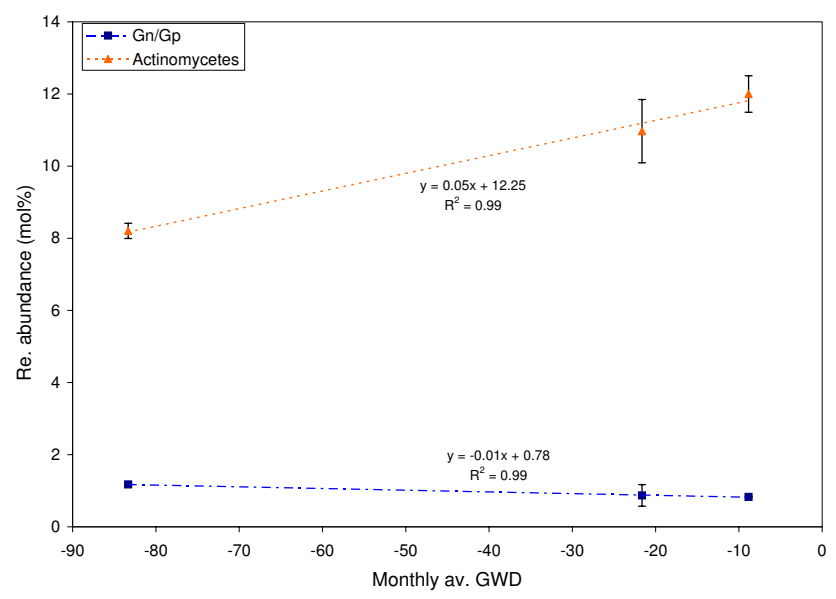

Fig. 7. Linear regression of monthly average ground water depth (GWD, cm) (over two years) vs. relative abundance of actinomycetes and $\mathrm{Gn} / \mathrm{Gp}$ (ratio between the relative abundances of gram negative bacteria and gram positive bacteria).

elatioris at the drier upper site. The effect of hydrology and vegetation composition on soil microbial community structures was investigated using SIP-PLFA technique. SIP-PLFA analysis showed greater relative abundance of aerobic gram negative communities in the surface layer of the upper site than that of the lower site, while the wetter lower site and the deeper soil layers were inhabited by gram positive bacterial communities. Despite their large abundance, the metabolically active proportion of gram positive bacterial and actinomycetes communities was less at both sites, suggesting their slow assimilation of root-derived $\mathrm{C}$ or dependence on other soil organic $\mathrm{C}$ sources. However, gram negative bacteria and fungi (18:1 $\omega 9 \mathrm{c}$ and $\mathrm{AMF})$ showed greater active involvement in assimilation of root-derived $\mathrm{C}$ at both sites. Ground water depth showed a significant effect on the relative abundance of several microbial communities. Relative abundance of gram negative bacteria significantly decreased with increasing GWD while the relative abundance of gram positive bacteria and actinomycetes at the surface layer increased with increasing GWD, suggesting that anaerobic conditions imposed by increasing GWD favor the abundance of gram positive bacteria and actinomycetes while gram negative bacteria prefers the aerobic surface layers where ground water is deep.

Acknowledgements. The authors wish to thank the special research fund (BOF) of Gent University and to the Fond voor Wetenschappelijk Onderzoek - Vlaanderen (FWO-Vlaanderen). D. Loete is greatly acknowledged for ecohydrological monitoring and help with the pulse labeling, J. Vermeulen and K. Van Nieuland are acknowledged for 13C-PLFA analysis.

Edited by: V. Iacobellis 


\section{References}

Anupam, B.: Mycorrhizae in wetlands: a review, Int. J. For. Manage., 4, 34-40, 2003.

Battaglia, L. L. and Collins, B. S.: Linking hydroperiod and vegetation response in Carolina bay wetlands, Plant Ecol., 184, 173$185,2006$.

Bardgett, R. D. and Shine, A.: Linkages between plant litter diversity, soil microbial biomass and ecosystem function in temperate grasslands, Soil Biol. Biochem., 31, 317-321, 1999.

Boon, P. I., Virtue, P., and Nichols, P. D.: Microbial consortia in wetland sediments: a biomarker analysis of the effects of hydrological regime, vegetation and season on benthic microorganisms, Mar. Freshwater Res., 47, 27-41, 1996.

Borga, P., Nilsson, M., and Tunlid, A.: Bacterial communities in peat in relation to botanical composition as revealed by phospholipid fatty acid analysis, Soil Biol. Biochem., 26, 841-848, 1994.

Boschker, H. T. S. and Middleburg, J. J.: Stable Isotopes and biomarkers in microbial ecology, FEMS Microbial Ecol., 40, 8595, 2002.

Boschker, H. T. S., Nold, S .C., Wellsbury, P., Bos, D., de Graaf, W., Pel, R., Parkers, R. J., and Cappenberg, T. E.: Direct linking of microbial populations to specific biogeochemical processes by C-13-labeling of biomarkers, Nature, 392, 801-805, 1998.

Bossio, D. A., Fleck, J. A., Scow, K. M., and Fuji, R.: Alteration of microbial communities and water quality in restored wetlands, Soil Biol. Biochem., 38, 1223-1233, 2006.

Bossio, D. A., Scow, K. M., Gunapala, N., and Graham K. J.: Determinants of soil microbial communities: effects of agricultural management, season, and soil type on phospholipid fatty acid profiles, Microb. Ecol., 36, 1-12, 1998.

Butler, J. L., Williams, M. A., Bottomley, P. J., and Myrold, D. D.: Microbial community dynamics associated with rhizosphere carbon flow, Appl. Environ. Microbiol., 69, 6793-6800, 2003.

Coles, J. R. P. and Yavitt, J. B.: Linking below ground carbon allocation to anaerobic $\mathrm{CH}_{4}$ and $\mathrm{CO}_{2}$ production in a forested peat land, New York State, Geomicrobiol. J, 21, 445-455, 2004.

Colmer, T. D.: Long-distance transport of gases in plants: a perspective on internal aeration and radial oxygen loss from roots, Plant. Cell. Environ., 26, 17-36, 2003.

Davidsson, T. E., Stepanauskas, R., and Leonardson, L.: Vertical patterns in nitrogen transformations during infiltration in two wetland soils, Appl. Environ. Microbiol., 63, 3648-3656, 1997.

Dawson, T. E., Mambelli, S., Plamboeck, A. H., Templer, P. H., and Tu, K. P.: Stable Isotopes in plant ecology, Ann. Rev. Ecol. Syst., 33, 507-559, 2002.

Denef K., Bubenheim, H., Lenhart, K., Vermeulen, J., Van Cleemput, O., Boeckx, P., and Muller, C.: Community shifts and carbon translocation within metabolically-active rhizosphere microorganisms in grasslands under elevated $\mathrm{CO}_{2}$, Biogeosciences, 4, 1-11, 2007,

http://www.biogeosciences.net/4/1/2007/.

Devito, K. J. and Hill, A. R.: Sulfate mobilization and pore water chemistry in relation to ground water hydrology and summer drought in two conifer swamps on the Canadian Shield, Water Air Soil Pollut., 113, 97-114, 1999.

Drijber, R. A., Doran, J. W., Parkhurst, A. M., and Lyon, D. J.: Changes in soil microbial community structure with tillage under long-term wheat-fallow management, Soil. Biol. Biochem., 32,
1419-1430, 2000.

Drissner, D., Wermbter, N., Niklaus, P. A., and Kandeler, E.: Nine years of enriched $\mathrm{CO}_{2}$ changes the function and structural diversity of soil microorganisms in a grassland, Eur. J. Soil Sci., 58, 260-269, 2007.

Ellenberg, H., Weber, H. E., Düll, R., Wirth, V., Werner, W., and Paulissen, D.: Zeigerwerte von Pflanzen in Mitteleuropa, 2nd edition: verbesserte und erweiterte Auflage, Scripta Geobotanica, 18, 1992.

Engel, V., Jobby, E. G., Stieglitz, M., Williams, M., and Jackson, R. B.: Hydrological consequences of Eucalyptus afforestation in the Argentine Pampas, Water Resour. Res., 41, W10409, doi:10.1029/2004WR003811, 2005.

Federle, T., Dobbins, D., Thornton-Manning, J., and Jones, D.: Microbial biomass, activity, and community structure in subsurface soils, Ground Water, 24, 365-374, 1986.

Fierer, N., Schimel, J. P., and Holden, P. A.: Variations in microbial community composition through two soil depth profiles, Soil Biol. Biochem., 35, 167-176, 2003.

Fritze, H., Pietikainen, J., and Pennanen, T.: Distribution of microbial biomass and phospholipid fatty acids in Podzol profiles under coniferous forest, Eur. J. Soil Sci., 51, 565-573, 2000.

Frostegard, A., Baath, E., and Tunlid, A.: Shifts in the structure of soil microbial communities in limed forests as revealed by phospholipid fatty acid analysis, Soil Biol. Biochem., 25, 723730, 1993.

Griffiths, B., Ritz, K., Ebblewhite, N., and Dobson, G.: Soil microbial community structure: effects of substrate loading rates, Soil Biol. Biochem., 31, 145-153, 1999.

Gutknecht, J. L. M., Goodman, R. M., and Balser, T. C.: Linking soil processes and microbial ecology in freshwater wetland ecosystems, Plant Soil, 289, 17-34, 2006.

Halbritter, A. and Mogyorossy, T.: Phospholipid fatty acid (PLFA) analysis of rhizosphere bacterial communities in a peat soil, Agrokemia et Talajtan, 51, 123-128, 2002.

Hill, M. O.: TWINSPAN - a FORTRAN program for arranging multi-variate data in an ordered two-way table by classification of the individuals and attributes, Cornell University, Ithaca, New York, 19, 1979.

Hume, N. P., Fleming, M. S., and Horne, A. J.: Denitrification potential and carbon quality of four aquatic plants in wetland microcosms, Soil. Sci. Soc. Am. J., 66, 1706-1712, 2002.

Ingham, E. R. and Wilson, M. V.: The mycorrhizal colonization of six wetland plant species at sites differing in land use history, Mycorrhiza, 9, 233-235, 1999.

Kennedy, A. C.: Rhizosphere, in: Principals and Applications of Soil Microbiology, edited by: Sylvia, D. M., Hartel, P. G., Fuhrman, J. J., and Zuberer, Z. A., Pearson Prentice, Hall publishing, Upper Saddle River, NJ, 309-407, 2005.

Leyer, I.: Predicting plant species' responses to river regulation: the role of water level fluctuations, J. Appl. Ecol., 42, 239-250, 2005.

Londo, G.: Decimal scale for releves of permanent quadrats, Vegetatio, 782, 61-64, 1976.

Lu, Y., Abraham, W. R., and Conrad, R.: Spatial variation of active microbiota in the rice rhizosphere revealed by in situ stable isotope probing of phospholipid fatty acids, Environ. Microbiol., 9, 474-481, 2007.

Mausbach, M. J. and Parker, W. B.: Background and history of the 
concept of hydric soils, in: Wetland soils, edited by: Richardson, J. L. and Vepraskas, M. J., Lewis, New York, 19-34, 2001.

Mentzer, J. L., Goodman, R., and Balser, T. C.: Microbial seasonal response to hydrologic and fertilization treatments in a simulated wet prairie, Plant Soil, 284, 85-100, 2006.

Olsson, P. A. and Johnson, N. C.: Tracking carbon from the atmosphere to the rhizosphere, Ecol. Lett., 8, 1264-1270, 2005.

Peters, J., Wieme, V., Boeckx, P., Samson, R., Godoy, R., Oyarzún, C., and Verhoest, N.: Ecohydrological monitoring in natural and managed ecosystems in Southern Chile, Gayana Botánica (Chilean journal), 62, 120-129, 2006.

Ponder, F. and Tadros, M.: Phospholipid fatty acids in forest soil four years after organic matter removal and soil compaction, Appl. Soil Ecol., 19, 173-182, 2002.

Prosser, J. I., Rangel-Castro, J. I., and Killham, K.: Studying plantmicrobe interactions using stable isotope technologies, Curr. Opin. Biotechnol., 17, 98-102, 2006.

Qiu, S. and McComb, A. J.: Drying-induced stimulation of ammonium release and nitrification in reflooded lake sediment, Mar. Freshwater Res., 47, 531-536, 1996.

Schaminée, J. H. J, Stortelder, A. H. F., and Weeda, E. J.: De vegetatie van Nederland, Deel 3: Plantengemeeschappen van graslanden, zomen en droge heiden, Opulus press, Uppsala, 356, 1996 (in Dutch).

Schaminée, J. H. J., Stortelder, A. H. F., and Westhoff, V.: De vegetatie van Nederland. Deel 2: Plantengemeeschappen van wateren, moerassen en natte heiden, Opulus press, Upsala, 1995 (in Dutch).

Schilling, K. E.: Water table fluctuations under three riparian land covers, Iowa (USA), Hydrol. Processes, 21, 2415-2424, 2007.

Smith, M. S. and Tiedje, J. M.: Phases of denitrification following oxygen depletion in soil, Soil Biol. Biochem., 11, 261-267, 1979.

Steer, J. and Harris, J. A.: Shifts in the microbial community in rhizosphere and non-rhizosphere soils during the growth of Agrostis stolonifera, Soil Biol. Biochem., 32, 869-878, 2000.
Sundh, I., Nilsson, M., and Borga, P.: Variation in microbial community structure in two boreal peat lands as determined by analysis of phospholipids fatty acid profiles, Appl. Environ. Microbiol., 63, 1476-1482, 1997.

Treonis, A. M., Ostle, N. J., Stott, A. W., Primrose, R., Graystone, S. J., and Ineson, P.: Identification of groups of metabolicallyactive rhizosphere microorganisms by stable isotope probing of PLFAs, Soil Biol. Biochem., 36, 533-537, 2004.

Van der Hoek, D. and Sykora, K. V.: Fen-meadow succession in relation to spatial and temporal differences in hydrological and soil conditions, Appl. Vegetation Sci., 9, 185-194, 2006.

Venterink, H. O., Davidsson, T. E., Kiehl, K., and Leonardson, L.: Impact of drying and re-wetting on $\mathrm{N}, \mathrm{P}$ and $\mathrm{K}$ dynamics in a wetland soil, Plant Soil, 243, 119-130, 2002.

Vestal, J. R. and White, D. C.: Lipid analysis in microbial ecology quantitative approaches to the study of microbial communities, Bioscience, 29, 535-541, 1989.

Waldrop, M. P., and Firestone, M. K.: Microbial community utilization of recalcitrant and simple carbon compounds: impact of oak-woodland plant communities, Oecologia, 138, 275-284, 2004.

Wetzel, P. R. and VanderValk, A. G.: Vesicular-arbuscular mycorrhizae in prairie pothole wetland vegetation in Iowa and North Dakota, Can. J. Bot., 74, 883-890, 1996.

White, D. C., Davis, W. M., Nickels, J. S., King, J. D., and Bobbie, R. J.: Determination of the sedimentary microbial biomass by extractable lipid phosphate, Oecologia, 40, 51-62, 1979.

White, W. N.: A method of estimating ground water supplies based on discharge by plants and evaporation from soil, United States, Geological Survey, Water-Supply Paper, 659A, 1932.

Williams, M. A., Myrold, D. D., and Bottomley, P. J.: Carbon flow from ${ }^{13} \mathrm{C}$-labeled straw and root residues into the phospholipid fatty acid of a soil microbial community under field conditions, Soil Biol. Biochem., 38, 759-768, 2006.

Zelles, L.: Phospholipid fatty acid profiles in selected members of soil microbial communities, Chemosphere, 35, 275-294, 1997. 